\title{
Visual Illustration Analysis on Dreadout Game Poster Through Semiotics
}

\author{
Wira Mahardika Putra \\ Department of Visual Communication \\ Design \\ Universitas Komputer Indonesia \\ Bandung, Indonesia \\ wira.mahardika@email.unikom.ac.id
}

\begin{abstract}
The purpose of this study is to analyze the meaning of visual illustration signs on Dreadout game posters. The method used in this study is semiotic developed by Ferdinand de Saussure. The visuals displayed in the Dreadout game poster show the visuals of five Indonesian high-school students and their teacher, ghost visualization Kuntilanak serves to emphasize the horror and scary nuances in the game, and the old house's background is very typical Indonesian designs in the past. The Dreadout logo is placed in the middle of the poster which indicates that the Dreadout game title is an identity and emphasizes the meaning of Dread Out itself, which means frightening. In analyzing the visual sign on this Dreadout poster, the visual signified and signifier in the poster are classified into four parts, namely the visual sign of six main human figures, a visual sign of a ghost character, a visual sign of an old house in the background, and a visual sign of the Dreadout logo and tag line. After that, the signs are analyzed in denotation meaning and connotation meaning. After reviewing, the results showed that the meaning that appears on the poster of the Dreadout game is easy to capture both denotation and connotation, the visuals of the poster also reflect Indonesian culture so that foreign players can feel the nuances of Indonesian culture built in this poster. Then it can be concluded that this poster has been good in conveying messages to the audience. The impact of this research is to add insight and provide an understanding the visual of the posters that used the theme of Indonesian local cultures can attract attention and become a unique selling point for domestic and foreign players.
\end{abstract}

Keywords - Game, Dreadout, Poster, Semiotics

\section{INTRODUCTION}

Game is one part of interactive multimedia that is popular with the society nowadays. If reviewed from the demographics of the game players, it will be found that this media is favored by various groups, ranging from children, teenagers, adults, men, and women, this is in accordance with Tay Vaughan's opinion [1]. One of the game studios from Indonesia is Digital Happiness Game Studio. This studio is from Bandung, West Java and was founded in 2011 with four members. One of the game that produced by Digital Happiness Game Studio is a horror themed game called Dreadout. Dreadout is a game aimed at the Microsoft Windows platform, this game was first released on April 3, 2013 and became the most popular horror game on intrenet and was the first Indonesian game played by foreign players.
The story in the Dreadout game itself is how the adventures of five high school students, namely Linda, Yayan, Ira, Shelly, and Doni and their teacher named Siska. They were stranded in an uninhabited city which turned out to be haunted and inhabited by various kinds of spirits.

Various types of media are used by Digital Happiness to promote the games they produce, ranging from video teasers, video trailers, posters, merchandise, and websites. Of all the media, the phenomenon of Dreadout posters is one of the most widely used and most widely distributed media through internet media. This is because the visuals of the poster reveal a distinctive appearance of Indonesian students with their uniforms and ghost visuals displayed along with horror nuances built in Indonesia, which is very interesting to study further.

Research on posters using signified and signifier semiotics of Ferdinand de Saussure [2] has been widely used, such as a study from Anania Hia, et al. [3] and Ranita Erlanti Harahap [4] who analyze the meaning of the sign that appears on the poster is very related, and the meaning that appears both denotatively and connotatively is easy to understand. The same thing was expressed by Deni Sofiansyah [5] and Farissa Ottoviano Atwaghosita [6] that the meaning of denotation and connotation that appeared must be easy to capture by the person who saw the poster.

Because in the previous research no one had discussed semiotic analysis on the game posters. So this study is aims to see how important the visual role of the illustration of the characters, the signified and signifier, the meaning of denotation meaning and connotations meaning, to the use of old house in the background that appears on the poster Dreadout game through Ferdinand de Saussure's semiotic analysis. Hopefully, this research can become reference of research related to semiotic analysis on posters.

\section{METHOD}

The research method used in this study is a qualitative descriptive research method. Qualitative descriptive method according to Nazir [7] is a method of examining the status of a group of people, an object, a set of conditions, a system of thought or a class of events in the present. The purpose of 
this descriptive research is to make a description, depiction, and illustrate with systematic, factual and accurate about the facts, characteristics and relationships between the phenomena investigated. Whereas according to Sugiyono [8] stated that descriptive method is a method used to describe or analyze a research result but not used to make broader conclusions. Based on this understanding, this study will look at the Dreadout game poster as an object that will be analyzed by classifying the signs that appear in the visual illustration of the poster and interpreting the meanings arising from the sign.

The analytical method used in this study is semiotic analysis. Semiotic analysis on the poster of the Dreadout game is to search and find the signs that appear, after that, to interpret the meaning that is non-verbal in visual objects. Semiotics itself cannot be separated from two figures namely Ferdinand de Saussure (1857-1913) and Charles Sanders Peirce (1839-1914). They are considered as pioneers of modern semiotics. Pierce identifies sign based on objects through three commonly used signs, namely: icon, index, and symbol. While Saussure propose that the system of significance is formed by a series of signs that are analyzed from the parts of its constituents, signified, and signifier. According to Daniel Chandler [9] the sign is a form or medium of sign, for example sound, image, scratches that form a word on the page, while the sign is understood based on concepts and meanings.

The Meaning in Ferdinand de Saussure's semiotics is divided into two, namely denotation meaning and connotation meaning. As expressed by Steven Bradley [10], the denotations and connotations both describe the relationship between signifier and signified, although each describes a different meaning. If the denotation describes the true meaning of the marker, the connotation describes the second meaning of the marker. Further, Nasrullah Mambrol [11] describe that denotation refers to the primary signification or reference, the definitional, literal, obvious meaning of a sign. In the case of linguistic signs, the denotative meaning is what the dictionary attempts to provide, while connotation refers to a range of associated significations, the socio-cultural and personal implications (ideological, emotional etc.) of the signs. These are typically related to the interpreter's class, age, gender, ethnicity and so on.

\section{A. Data Collecting}

The first stage is by collecting data for the purposes of this study, there are several approaches taken. The first approach is observation on the object which is Dreadout game poster that published in 2013 produced by Digital Happines Game Studio. In observation, poster of the game searched using internet media. The next approach used is literature study. Literature study is the study of data collection using media such as books, articles and scientific research on the visual communication design, posters, semiotics, signs and related research methodologies. Some articles from related print media and internet media sources are also used.

\section{B. Data Processing}

After collecting data with direct observation methods and literature studies, the data will be processed to obtain valid results. The results of direct observation and literature studies were then summarized, classified and processed to be adjusted to the analysis model. Supporting data in the form of documents from various sources is processed to strengthen arguments and enrich the material.

The next stage is the visual analysis phase of the visual illustrated Dreadout game poster produced by Digital Happiness Game Studio. At this stage, visual elements will be described in the object of research. Through the analysis of this sign will get a description of the sign elements that appear along with their meaning.

\section{RESULTS}

The results of visual analysis of illustrations from the Dreadout game poster through semiotics can be concluded into several points, such as:

1. Six human characters appearing on the Dreadout game poster are the six main characters of this game. Relations between characters are five high school students named Linda, Ira, Shelly, Yayan, and Doni, and their teacher named Siska. The six of them have a close emotional bond which can be seen from their standing positions that are close together and they appear as they are.

In terms of the clothesthat being worn, it was very noticeable that the five students were Indonesian high school students, it can be identified from the school uniform that being worn. As for Siska character, it's wearing non-formal clothes, it is become not too obvious that Siska's character is a teacher of her five students.

2. The visual of the Kuntilanak ghost character that was illustrated gave the meaning that Linda and his friends had to face the ghosts who would attack them, including the Kuntilanak ghost. The appearance of this ghost also wants to build a horror impression. In terms of visual appearance, the Kuntilanak ghost is the same visual according to the myth that developed in Indonesia.

3. Visual of the old house in the background means giving affirmation of the setting in abandoned places for decades and is one of the places that will be explored by the character Linda in the game. The old house has a typical Indonesian architectural design in the past which also affirmed that the place had not been inhabited for a long time and had a haunted impression.

4. The letter $\mathrm{O}$ on the Dreadout logo is a visualization of the Ouroboros dragon which has the meaning of immortality, the beginning and the end, the life and the death. The Ouroboros here depicted a message that in her journey, Linda had to face the ghosts by risking his life and the lives of her friends. A condition where life and death are very close to the Linda. The immortality here is a representation of the ghosts that appear in the game is previously an ordinary human who performs the rituals of darkness or humans who died but still 
have ties to the world because of their desires that have not yet be realized so it makes them haunted ghosts.

The tagline that was used contain a message that this game was a horror type game and the setting of the event is based on the cultural approach of Indonesian culture.

\section{DISCUSSION}

The Dreadout game poster was first released in 2013 with the aim of promoting a horror themed game from Indonesia produced by Digital Happiness Studio which is planned to be released in 2014 as the final version. After the release, this Dreadout game received a positive response from various groups both domestically and abroad, this game also became the most widely played horror game at the time and was an original game made in Indonesia which was widely played by foreign players.

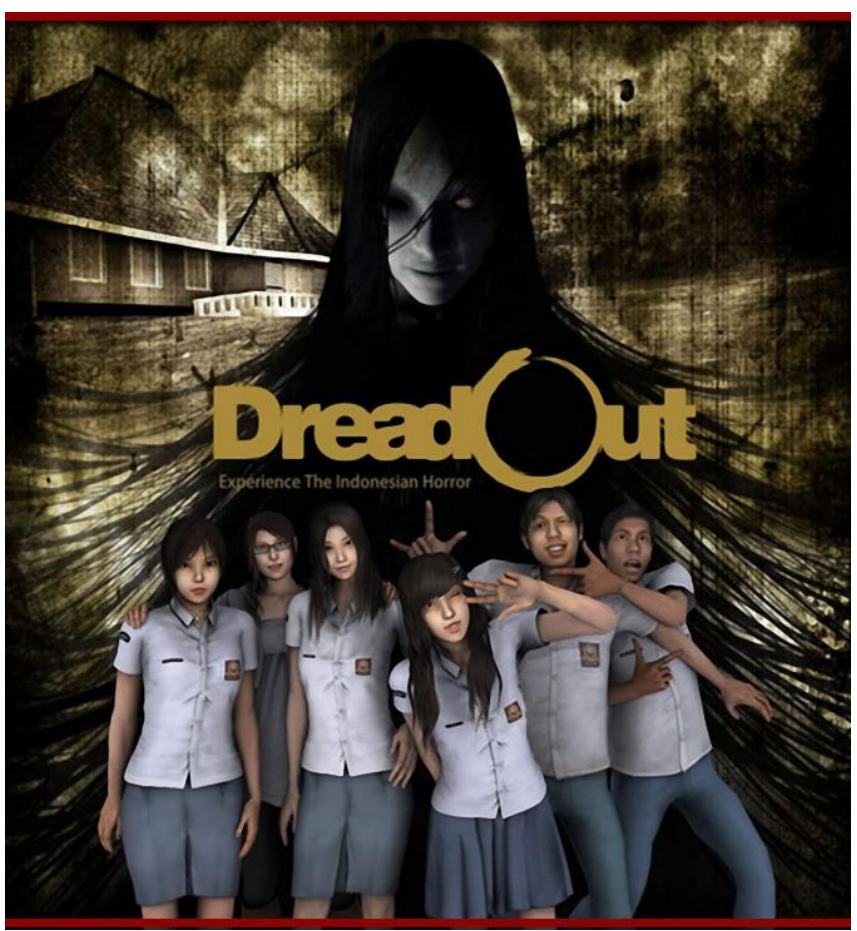

Figure 1. Dreadout game poster

The visual meaning that appears on the poster of the Dreadout game in Figure 1 above will be classified into four parts that analyzed through semiotics, including visual meaning of six main human characters, visual meaning of one ghost character, visual meaning of old house in the background, and visual meaning of Dreadout logo along with the tagline used in the poster.
TABLE I The Visual Meaning of Six Main Human CHaracter

\begin{tabular}{|l|l|l|}
\hline \multirow{2}{*}{ Signified } & \multicolumn{2}{|c|}{ Signifier } \\
\cline { 2 - 3 } & \multicolumn{1}{|c|}{ Denotation } & \multicolumn{1}{c|}{ Connotation } \\
\hline $\begin{array}{l}\text { Six Characters } \\
\text { who stand } \\
\text { close together }\end{array}$ & $\begin{array}{l}\text { - Five people } \\
\text { wearing } \\
\text { Indonesian style } \\
\text { high school } \\
\text { uniforms }\end{array}$ & $\begin{array}{l}\text { - Six characters } \\
\text { who became the } \\
\text { center of the story } \\
\text { from the Dreadout } \\
\text { game }\end{array}$ \\
& $\begin{array}{l}\text { One character } \\
\text { wears non-formal } \\
\text { clothing }\end{array}$ & $\begin{array}{l}\text { These six } \\
\text { characters have } \\
\text { emotional } \\
\text { closeness because } \\
\end{array}$ \\
& $\begin{array}{l}\text { The names of the } \\
\text { they look familiar } \\
\text { six characters are } \\
\text { Linda, Siska, Ira, } \\
\text { Shelly, Yayan, } \\
\text { to each other }\end{array}$ \\
& $\begin{array}{l}\text { and Doni (from } \\
\text { left to right) }\end{array}$ & \\
&
\end{tabular}

The visuals of six people who were close together were a group of high school students named Linda Mellinda (Linda), Sakhira Irawati (Ira), Shelly Angelia (Shelly), Yayan Ruhian (Yayan), and Doni Maulana (Doni) who were away in the field trips with their teachers named Mariska Gandasasmita (Siska). They unwittingly lost their way and were stranded in an uninhabited and haunted city.

The denotation meaning that is built is that Linda, Ira, Shelly, Yayan, and Doni are Indonesian high school students. This can be seen from Yayan and Doni's uniforms that are typical for male high school students, as follows:

1. White shirt, short sleeves with one pocket on the left chest of the shirt

2. Pants in gray, length of pants to ankles, there are pockets on the right and left sides of pants

3. A brown OSIS badge on the shirt pocket.

4. Student name badge is located in the right chest shirt

5. The school name badge is located on the right arm of the shirt

While the High School uniforms of Linda, Shelly, and Ira when analyzed by its denotation meaning are as follows:

1. White shirt, short sleeves with one pocket on the left chest of the shirt

2. The skirt is gray, the length of the skirt is $5 \mathrm{~cm}$ below the knee, there is a pocket on the right side of the skirt

3. A brown OSIS badge on the shirt pocket.

4. Student name badge is located in the right chest shirt

5. The school name badge is located on the right arm of the shirt

Based on the results of the visual analysis above, it can be concluded that the visualization of the uniforms that being worn is in accordance with government regulations regarding SMA National Uniforms[12]. As for Siska, She is visualized not wearing teacher uniforms accordance with government regulations but using a non-formal clothes. 
When interpreted in terms of connotation, these six character have emotional closeness to each other where the six character are visualized with their positions close together and with the same visual size. Nothing is enlarged or reduced so that all the characters have same focal point.

TABLE II. The Visual Meaning of ONe GHost CAHARacter

\begin{tabular}{|l|l|l|}
\hline \multirow{2}{*}{ Signified } & \multicolumn{2}{|c|}{ Signifier } \\
\cline { 2 - 3 } & \multicolumn{1}{|c|}{ Denotation } & \multicolumn{1}{c|}{ Connotation } \\
\hline $\begin{array}{l}\text { One character } \\
\text { is behind the } \\
\text { other six } \\
\text { characters and } \\
\text { have a larger } \\
\text { size visually }\end{array}$ & $\begin{array}{l}\text { - A ghost character } \\
\text { named } \\
\text { Kuntilanak who } \\
\text { smiled } \\
\text { meaningfully }\end{array}$ & $\begin{array}{l}\text { - The level of } \\
\text { urgency of the } \\
\text { game is against a } \\
\text { creepy ghost }\end{array}$ \\
& $\begin{array}{l}\text { Kuntilanak is one } \\
\text { of the ghosts } \\
\text { Linda will fight in } \\
\text { the game } \\
\end{array}$ & $\begin{array}{l}\text { Kuntilanak is one } \\
\text { of the ghosts that } \\
\text { are difficult to } \\
\text { defeat }\end{array}$ \\
& & \\
& & \\
\end{tabular}

Kuntilanak ghost character in poster, if interpreted denotatively is a supernatural creature who has a creepy appearance with pale skin color, smirking smile, right eyeball is not present while the left eyeball is visible but the pupils are not visible, and the length of the hair is very long and spread almost half of the poster.

If it is examined from the meaning of its connotation, the visual of Kuntilanak's ghost is one of the ghosts that Linda and friends in the game will fight later. For the visual size of the figure was made larger than other figures, this is an emphasis that the ghost character is an important character who will play an important role in the game story. This is in line with the gameplay where the Kuntilanak character is one of the ghosts that is difficult to defeat. When reviewed from the position of visual placement in the middle, it can be interpreted that the poster maker wants to bring the impression of how creepy the Kuntilanak ghost is that the players will have to fight.

TABLE III. The Visual MeAning of The Old House In The BACKGROUND

\begin{tabular}{|l|l|l|}
\hline \multirow{2}{*}{ Signified } & \multicolumn{2}{|c|}{ Signifier } \\
\cline { 2 - 3 } & \multicolumn{1}{|c|}{ Denotation } & \multicolumn{1}{c|}{ Connotation } \\
\hline $\begin{array}{l}\text { The old house } \\
\text { in the } \\
\text { background }\end{array}$ & $\begin{array}{l}\text { - Old house which } \\
\text { is one of many } \\
\text { place that can be } \\
\text { explore in the } \\
\text { game }\end{array}$ & $\begin{array}{l}\text { Affirmation of the } \\
\text { place where } \\
\text { various kinds of } \\
\text { ghost attacks will } \\
\text { occur }\end{array}$ \\
\hline
\end{tabular}

Based on the meaning of denotation, the visual illustration of the old house in the background serves as one of many places where Linda can explore in the game.

The connotation of the meaning of this old house is the place where various kinds of mystical events and attacks from ghosts will be confronted by the character Linda. In this old house was the first meeting of character Linda with the ghost character Kuntilanak.

TABLE IV. The Visual Meaning of the Dreadout Logo And The TAGLINE

\begin{tabular}{|c|c|c|}
\hline \multirow{2}{*}{ Signified } & \multicolumn{2}{|c|}{ Signifier } \\
\hline & Denotation & Connotation \\
\hline $\begin{array}{l}\text { Dreadout } \\
\text { game logo and } \\
\text { the tagline }\end{array}$ & $\begin{array}{l}\text { - Logo of the } \\
\text { Dreadout game } \\
\text { which is a } \\
\text { logotype type } \\
\text { with the letter O } \\
\text { in the form of a } \\
\text { dragon } \\
\text { - The tagline used } \\
\text { by the Dreadout } \\
\text { game is } \\
\text { Experience the } \\
\text { Indonesian } \\
\text { Horror }\end{array}$ & $\begin{array}{l}\text { - The function to } \\
\text { positioning the } \\
\text { game title in the } \\
\text { center of the } \\
\text { poster is that the } \\
\text { reader will be } \\
\text { directly focused } \\
\text { on the game title } \\
\text { - The meaning of } \\
\text { the game title is } \\
\text { an affirmation } \\
\text { that this game is } \\
\text { very scary } \\
\text { - Dragon in the } \\
\text { logo called } \\
\text { Ouroboros which } \\
\text { has the meaning } \\
\text { of immortality, } \\
\text { the beginning and } \\
\text { the end, the life } \\
\text { and the death } \\
\text { - Tagline is an } \\
\text { affirmation } \\
\text { regarding the type } \\
\text { of horror game } \\
\text { originating from } \\
\text { Indonesia. }\end{array}$ \\
\hline
\end{tabular}

By denotation meaning, the Dreadout game logo is a logotype type logo with dreadout writing clearly visible which serves to tell the title of this game. In the letter $\mathrm{O}$ of the word Dreadout is visually illustrated with a dragon named Ouroboros. The tagline of this game is positioned close to the game title with Experience the Indonesia Horror writing.

If it is interpreted connotatively, the Dreadout game logo means that this game will display a variety of scary visuals. In the $\mathrm{O}$ letter of the word Dreadout, the Ouroboros dragon is based on Ancient Egyptian beliefs, Ouroboros is a very large dragon that eats its own tail. This is believed to be a symbol of immortality, the beginning and the end of something, and the symbolization of the life and the death. In the tagline section there is a sentence which is the emphasis and affirmation that this game is a horror game with ghost characters, place settings, and indigenous Indonesian culture.

\section{CONCLUSION}

Based on the analysis that has been done using semiotics, it can be concluded that the poster of the Dreadout game is good at displaying the visual illustration where the message 
to be conveyed is well received, both in terms of denotation meaning that displays the characters who will be the center of the story and its place setting as well as in terms of connotation meaning that there is clearly a good emotional connection to the six characters in the game and how the Kuntilanak ghost becomes a focal point which is a representation of the horror nuances built in the game and is the main point in this Dreadout game. Another positive value from the visual illustration of the poster of the Dreadout game is the element of Indonesian local culture which is very solid seen from the clothes worn, the visual design of human character as well as the design of ghost character, as well as the place where they appear.

\section{ACKNOWLEDGMENT}

The author expressed his highest gratitude to the presence of Allah SWT. The author thanks to the family for encouraging and support the authors, also many thanks for the institutions that have provided motivation to the authors to continue to develop their knowledge.

\section{REFERENCES}

[1] T. Vaughan, "Multimedia: Making It Work, Eight Edition. New York, Mc Graw Hill Press, 2011
[2] F. de Saussure, "Pengantar Linguistik Umum". Gadjah Mada University Press, 1993

[3] A. Hia, et al, "Analisis Semiotik Poster Lingkungan". Universitas Bung Hatta.

[4] R. Erlanti Harahap, "Analisis Semiotik Pada Poster HIV/AIDS di Yayasan Pelita Ilmu". UIN Syarif Hidayatullah, 2008.

[5] D. Sofiansyah, "Analisis Semiotik Pada Poster Anti Merokok Departemen Kesehatan RI". UIN Syarif Hidayatullah. 2010.

[6] F. Ottaviano Atwaghosita. "Perbandingan Makna Verbal pada Poster Film The Avengers Versi Jepang dan Original: Kajian Semiotik". Japanology Vol 2, No. 2. 2014

[7] M. Nazir, "Metode Penelitian". Ghalia Indonesia: Jakarta. 1988

[8] Sugiyono, "Metode Penelitian Administratif". Bandung: Alfabeta. 2005

[9] D. Chandler, "Semiotics for Beginner". http://visualmemory.co.uk/daniel/Documents/S4B/sem06.html. 10-8-2018.

[10] S. Bradley. "Denotation and Connotation-Literal Meaning and Implied Meaning". https://vanseodesign.com/web-design/denotationconnotation/. 9-8-2018.

[11] N. Mambrol. "Literacy Theory and Criticism Notes, Connotation and Denotation". https://literariness.org/2016/03/18/connotation-anddenotation/. 9-8-2018.

[12] Peraturan Kementrian Pendidikan dan Kebudayaan No. 45 tahun 2014. 